Original Paper http://ajol.info/index.php/ijbcs http://indexmedicus.afro.who.int

\title{
Hygienic quality of ready-to-eat salads sold in the street and a modern restaurant in Lomé, TOGO
}

\author{
K. SONCY, K. ANANI, B. DJERI, Y. ADJRAH, M.M. EKLU, D.S. KAROU *, \\ Y. AMEYAPOH and C. DE SOUZA
}

\author{
Laboratoire de Microbiologie et de Contrôle de Qualité des Denrées Alimentaires (LAMICODA), Ecole \\ Supérieure des Techniques Biologiques et Alimentaires (ESTBA), Université de Lomé, BP 1515, Lomé, Togo. \\ *Corresponding author, E-mail: simplicekarou@hotmail.com
}

\begin{abstract}
Poisoning following salads consumption was often reported in Lomé. This study was carried out to evaluate contamination of salads sold in Lomé. Sixty salad samples from modern restaurant (Domino), seventy from street sellers and forty of fresh vegetables from two markets were randomly collected. Microbiological quality of samples was examined on the basis of AFNOR methods and criteria. Salad selling occurs in room temperature. That modern restaurant uses cold to preserve foods. Microbial analyzes revealed that, Total viable count (TVC) load ranged from $2.15 \times 10^{4}-9.2 \times 10^{10}$ and $1.8 \times 10^{3}-2.7 \times 10^{7}$ with $10 \%$ and $86.66 \%$ of satisfactory quality samples respectively for Domino and Street salads. Total and thermo-tolerant coliforms load ranged from $60-3.4 \times 10^{6}$ and $0-6.2 \times 10^{3}$ respectively for street salads with $14.28 \%$ and $57.15 \%$ of satisfactory samples. Domino samples located between $0-7 \times 10^{3}$ and $0-2.5 \times 10^{3}$ with $96.66 \%$ and $81.33 \%$ of conformity respectively. E. coli and $S$. aureus were isolated $\left(0-2.5 \times 10^{3}\right.$ and $\left.0-10^{3}\right)$ respectively with $77.14 \%$ and $84.28 \%$ of satisfactory samples for street salads. These bacteria did not induce any conform samples. Salmonella spp were not found in salads and raw vegetable. Application of good hygiene practices rules would help to reduce disease risk related to the presence of pathogenic germs like E. coli and S. aureus.
\end{abstract}

(c) 2015 International Formulae Group. All rights reserved.

Keywords: Food poisoning, Vegetable food, microbiological safety.

\section{INTRODUCTION}

Fast urbanization of sub-Saharan African cities results in food demand increase (Temple et al., 2005; David-Benz et al., 2005). Therefore, food businesses become widespread, in response to lifestyle changing and food consumption of people. Food businesses offer convenience and easy access to food for those, who are unable to prepare their own meals regularly at home. In large scale cooking, food passes through many hands, thereby increasing the chances of food contamination due to improper handling (Amponsah-Annor and Anamoaba-Baiden, 2011). Over the past few years, Lomé people and those of other towns of developing countries are eating more meals outside their houses (Noraziah and Mohd, 2012). This is due to the socio-professional changes in population. As a matter of fact, the restaurants number is increasing every day; the "takeaway" and fast food services as well as 
services of food hawkers are part of the new way of eating outside in the cities.

The salad selling activities on the street have become a common aspect of lifestyle in Lomé. Ready-to-eat (RTE) salads constitute an expanding food commodity nowadays served to the consumers (Carrasco et al., 2010; Arvanitoyannis et al., 2011; Adjrah et al., 2013). Today, this standard food is being proposed to the customers by itinerant vendors or in street restaurants, takeaways and fast food services in the schools and public places of Lomé. Salad can be defined as a food made primarily of a mixture of raw vegetables and/or fruits (Uzeh et al., 2009; Rajvanshi, 2010). Vegetables are a good source of antioxidants and phytonutrients, and have health protecting properties (Meng et al., 2002; Vrchovska et al., 2006), to improve human well-being. They generate little calories to the consumers but are rich in carbohydrates, vitamins and minerals (Rajvanshi, 2010). In contrast, salads of raw vegetables may be unsafe, mainly because of the poor environment where they are prepared and consumed (Taban et al., 2011). Contamination of food during large production might endanger the health of consumers, and have very expensive repercussions on a country (Amponsah-Annor and Anamoaba-Baiden, 2011).

Togo, as many other developing countries, had not yet established appropriate monitoring or reporting mechanisms to identify and track foodborne illnesses. The Directories of the medical statistics raised in Lomé, 393 cases of foodborne infection in 2002, 49 cases with 6 deaths in 2003. In 2005, there were 139 cases declared with 32 deaths. Therefore, data on foodborne diseases are extremely scarce and improvements are needed to better identify the causes of foodborne diseases. The symptoms of foodborne illnesses like nausea, diarrhea, fever and vomiting are often observed in people having taken part in garden party where they consumed salads. In view of the flourishing demand for such street vended salads and the potential threat posed, this study was undertaken to evaluate the health hazards to which are exposed the salad consumers in Lomé.

\section{MATERIALS AND METHODS}

\section{Study area}

Lomé, where this study proceeded, is the capital of Togo. It is located at the extreme south-west of Togo, and extends along the sea coast from the Gulf of Guinea. The urban area counted with the census of 2010 mounts to 1 477.660 inhabitants, while the city counts 837.437 inhabitants. The active part represents nearly $80 \%$ of this population. (Lambony and Nyassogbo, 2008)

\section{Collection of samples}

Seventy samples of salads were randomly collected from food shops located along the streets and some schools in districts of Gbadago, Atikoume and Tokoin N'tifafa Kome. Sixty samples of salads were collected from a restaurant called Domino, located in Bè district. Forty samples of salad ingredients were also obtained from the market of Atikpodzi and Abattoir. All salads samples were mainly constituted with lettuce mixed with other vegetables (cabbage, cucumber, beet, onion, carrots, and tomatoes), eggs, gratin of meat and fish, ingredients (mayonnaise, vinegar, oil and salt). The study was carried out from June to April 2014.

Approximately, 250 to $300 \mathrm{~g}$ of each sample was aseptically collected and placed in labeled sterile polyethylene bags and transported in an ice box to the laboratory. The samples were either immediately analyzed after arrival in the laboratory. Structured questionnaires, extensive observation and interviews were used for the study involving all the food vendors and Domino staff. 


\section{Samples Preparation}

From each salad sample, $25 \mathrm{~g}$ was aseptically weighed in $225 \mathrm{ml}$ of buffered peptone water (BPW) and blended vigorously for 2 min at normal speed in a kitchen blender (Moulinex, France) to prepare initial suspensions. Serial dilutions (10-1 to $10-5)$ were carried out using sterile Tryptone salt (TS) as diluents.

\section{Sample analysis}

The microbial analysis concerns the following germs and methods: total aerobic flora (NF V08-051), total coliforms (NF V08050), thermo-tolerant coliforms (NF V08016), anaerobic sulfite-reducing bacteria (XP V08-061), Staphylococcus aureus (NF V08057-1), fungi (NF V08-075) and Salmonella spp (NF V08-052). All media used were purchased from Bio Rad (France). Microbial enumeration was performed as follows: $1 \mathrm{ml}$ from initial suspensions or serial decimal dilutions was used to inoculate Petri dishes incubated in appropriate conditions. Colony count was performed in dishes with between 30 and 300 colonies. Results were expressed as colony forming units (CFU/ml).

Total viable bacteria were determined with Plate Count Agar (PCA) after $72 \mathrm{~h}$ incubation at $30{ }^{\circ} \mathrm{C}$. Total coliforms and thermo-tolerant coliforms were enumerated on Violet Red Bile Lactose (VRBL) agar after 24 $\mathrm{h}$ incubation at $30^{\circ} \mathrm{C}$ and $44^{\circ} \mathrm{C}$, respectively.

Anaerobic sulfite-reducing bacteria (ASR) were assessed with Tryptone-Sulfite Neomycin (TSN) agar after $48 \mathrm{~h}$ incubation at $44{ }^{\circ} \mathrm{C}$. Sabouraud-Chloramphenicol agar was used for the isolation and identification of Yeast and Moulds, and plates were incubated for 3 to 5 days at $25{ }^{\circ} \mathrm{C}$. Pure isolates of Mould were identified by using microscopic complete with macroscopic characteristics of the colonies. For $S$. aureus counts, $0.1 \mathrm{ml}$ of appropriates dilutions were spread on BairdParker agar plates supplemented with egg yolk-tellurite emulsion (Bio Rad). The plates were then incubated at $37{ }^{\circ} \mathrm{C}$ for 24 to $48 \mathrm{~h}$. Each typical colony of $S$. aureus (black smooth colonies showed convex to uniform outline with one clear halo) was sub cultured in nutrient agar $\left(37{ }^{\circ} \mathrm{C}, \quad 24 \mathrm{~h}\right.$. Colonies obtained on the last agar were examined microscopically, tested for Gram and catalase reactions, and confirmed by coagulase activity (rabbit plasma, Bio Rad). Buffered Peptone Water (BPW) was used for pre-enrichment at $37{ }^{\circ} \mathrm{C}$ for $24 \mathrm{~h}$; followed by enrichment at 37 ${ }^{\circ} \mathrm{C}$ for $24 \mathrm{~h}$ with Rappaport Vassiliadis soya broth prior to isolation and counting on Hektoen and SS agar at $37{ }^{\circ} \mathrm{C}(24 \mathrm{~h})$ Salmonella spp. Characteristics colonies were identified by API $20 \mathrm{E}$ test system which used 23 miniaturized biochemical tests (Bio Merieux, France).

"Association Française de Normalisation (AFNOR)" limits for frozen vegetables were used to appreciate the conformity of the analyzed samples: Total aerobic bacteria $\left(30{ }^{\circ} \mathrm{C}\right), 5 \times 10^{5} \mathrm{cfu} / \mathrm{g}$; Total coliforms $\left(30{ }^{\circ} \mathrm{C}\right), 3 \times 1000 \mathrm{cfu} / \mathrm{g}$; Thermotolerant coliforms $\left(44{ }^{\circ} \mathrm{C}\right), 15 \mathrm{cfu} / \mathrm{g}$; Anaerobic sulfite-reducing bacteria, $10 \mathrm{cfu} / \mathrm{g}$; S. aureus $\left(37{ }^{\circ} \mathrm{C}\right), 10 \mathrm{cfu} / \mathrm{g}$; Moulds $\left(30{ }^{\circ} \mathrm{C}\right)$, $1000 \mathrm{cfu} / \mathrm{g}$; Yeasts $\left(30^{\circ} \mathrm{C}\right), 500 \mathrm{cfu} / \mathrm{g}$; the Salmonella $0 \mathrm{cfu} / 25 \mathrm{~g}$.

\section{Statistical analysis}

The experimental data were analyzed using Analysis of Variance (ANOVA) to determine significant difference between the data of the samples analyzed. t-test was used to see whether compared to the results; the Domino salad was contaminated more than those of streets. The level of significance was set at $\mathrm{p} \leq 0.05$. The data were analyzed using SYSTAT 11.

\section{RESULTS \\ Investigation results}

In the street, more than $78.57 \%$ of fresh salads vendors were women. Their selling activities took place under sheds $(44 / 70)$ or trees $(16 / 70)$ in an area polluted by dust and vehicle exhaust fumes. Few of them (10/70) did their selling activities in the huts installed at the edge of the streets. Raw salad ingredients were bought the day before in Lomé markets. Some of them, $28.53 \%$ carried an apron during the selling activity. All of vendors used spoon to serve salad to the 
customers. The majority of sellers $(72.85 \%)$ receive money by left hand. The selling activities were done from 9 a. m. to $3 \mathrm{p}$. m. on room temperature $\left(29^{\circ} \mathrm{C}\right.$ to $\left.35^{\circ} \mathrm{C}\right)$. Potassium permanganate solution and drinking water were used to wash vegetables. In their majority, street vendors used plastic plates to serve salad. The plates after using were washed by waiters in only one bath of soap and flushing water.

In the Domino restaurant, fresh salad production was organized in accordance with good hygiene, manufacturing and conservation practices. Purchasing, receiving, washing, storage, processing, serving and reserving of fresh product were done according to a validated process. Activities in this restaurant were carried out according to walkahead principle in order to avoid cross contamination. At the reception, the quality of raw material was evaluated by the quality manager. All food products received specific treatment according to their nature (sorts, cleaning, cutting, cooking, bleaching, etc.) before being preserved until the use Chlorine and vinegar are used to clean vegetables. Then, the vegetables were kept in clean containers in a freezer or a refrigerator.

\section{Analysis results}

The results obtained for microorganisms count showed that the total viable flora counts (TVC) for fresh salads ranged from $2.15 \times 10^{4}$ to $9.2 \times 10^{10} \mathrm{cfu} / \mathrm{g}$ and that $10 \%$ of samples analyzed were conform in accordance with the AFNOR limits. TVC for fresh vegetable ranged from 50 to $2 \times 10^{9}$ cfu/g with $52.5 \%$ samples conform (Figure 1). It also showed that the total coliform counts for fresh salad ranged from 60 to $3.4 \times 10^{6}$ $\mathrm{cfu} / \mathrm{g}$ and fresh ingredients germs count ranged from 0 to $2.5 \times 10^{5} \mathrm{cfu} / \mathrm{g}$. Thermotolerant coliforms counts ranged from 0 to 6.2 $\mathrm{x} 10^{3} \mathrm{cfu} / \mathrm{g}$ for fresh salad and 0 to $7 \times 10^{4}$ $\mathrm{cfu} / \mathrm{g}$ for fresh ingredients. Concerning total coliforms, $14.28 \%$ of salad samples and $60 \%$ of fresh ingredients analyzed were conform to the criteria used. According to Thermotolerant coliforms, $57.14 \%$ and $60.25 \%$ of salad and fresh ingredients samples respectively were conform to the criteria. Escherichia coli were found in $22.86 \%$ of salad and $20 \%$ of raw vegetables samples. The results indicated that $E$. coli count ranged from 0 to $2.5 \times 103 \mathrm{cfu} / \mathrm{g}$ and from 0 to 120 respectively in salad and raw vegetables samples analyzed. S. aureus counts showed that $15.72 \%$ of salad samples and $12.50 \%$ of raw vegetable samples do not conform. ASR induced non conformity to $20 \%$ and $7.5 \%$ in salad and fresh ingredients samples respectively. Yeasts and Moulds counts induced $7.15 \%$ and $1.42 \%$ salad samples did not fit the standard (Figure 3) and in the same way for $12.50 \%$ and $2.5 \%$ raw vegetables samples (Figure 1). Salmonella did not isolate in any sample of salads and fresh ingredients samples analyzed.

Salads samples collected from Domino catering $(n=60)$ were analyzed and the results are shown in Figure 2. According to total aerobic count, $86.66 \%$ of salads samples were conform ; $96.66 \%$ and $81.33 \%$ of samples, were conform respectively to Total coliforms and Thermo-tolerant coliforms criteria. All of salads samples (100\%) analyzed were conforms to S. aureus (0 to 80 cfu/g). E. coli, Salmonella, ASR, Yeasts and Moulds were not founded in any samples of salad produced by Domino catering. Compared to the Total viable count bacteria, there is no significant difference between samples of Domino and those bought in the street $(p=0.124)$, between fresh vegetables and street salads $(p=0.225)$ and between fresh vegetables and salads produced by Domino $(\mathrm{p}=0.192)$. Significant difference $(\mathrm{p}<0.05)$ was observed in levels of coliforms contamination of salad and fresh vegetable analyzed. 


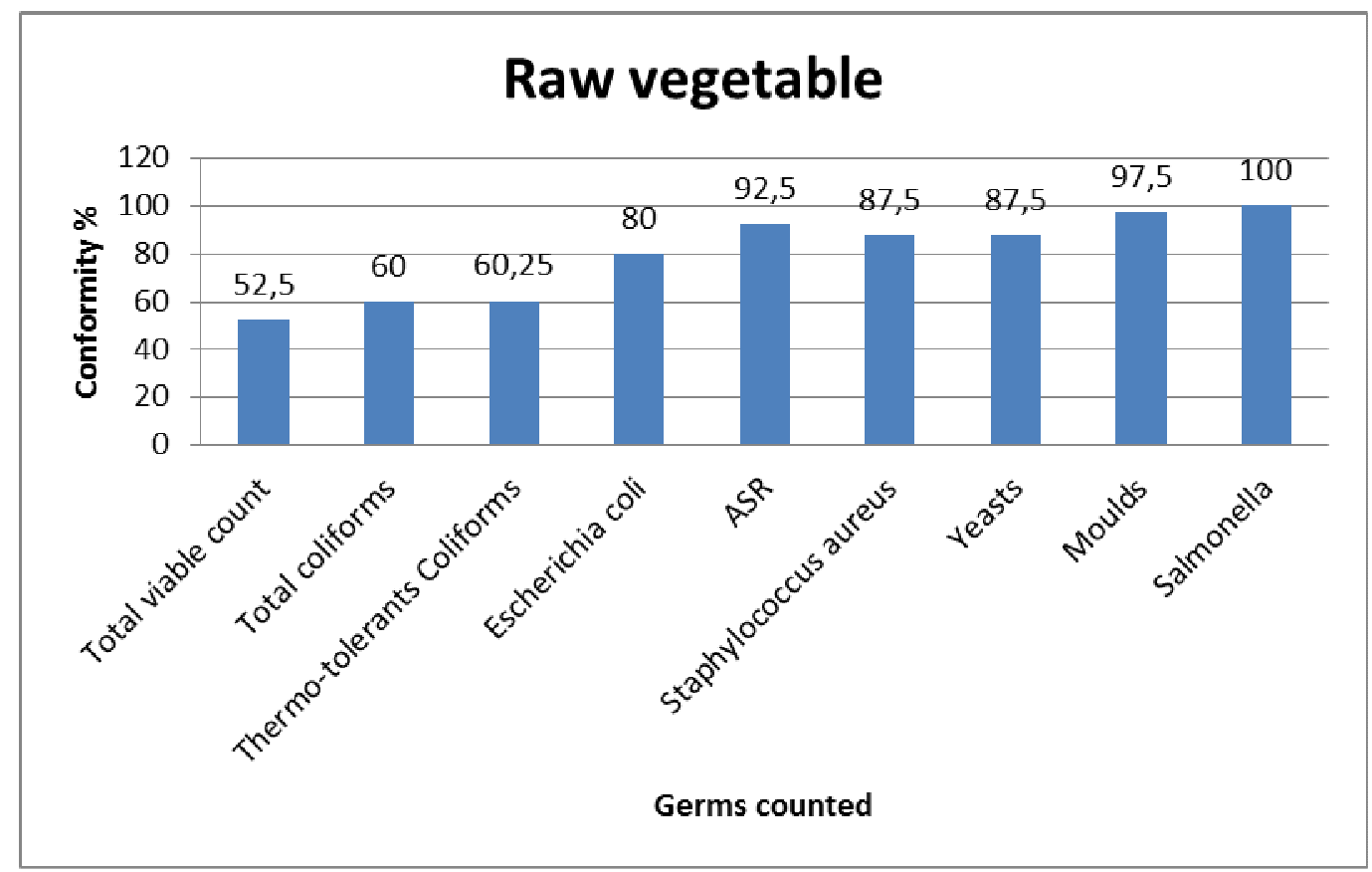

Figure 1: Compliance $(\%)$ level of raw vegetable samples compared to the germs. ASR = Anaerobic sulfite-reducing bacteria.

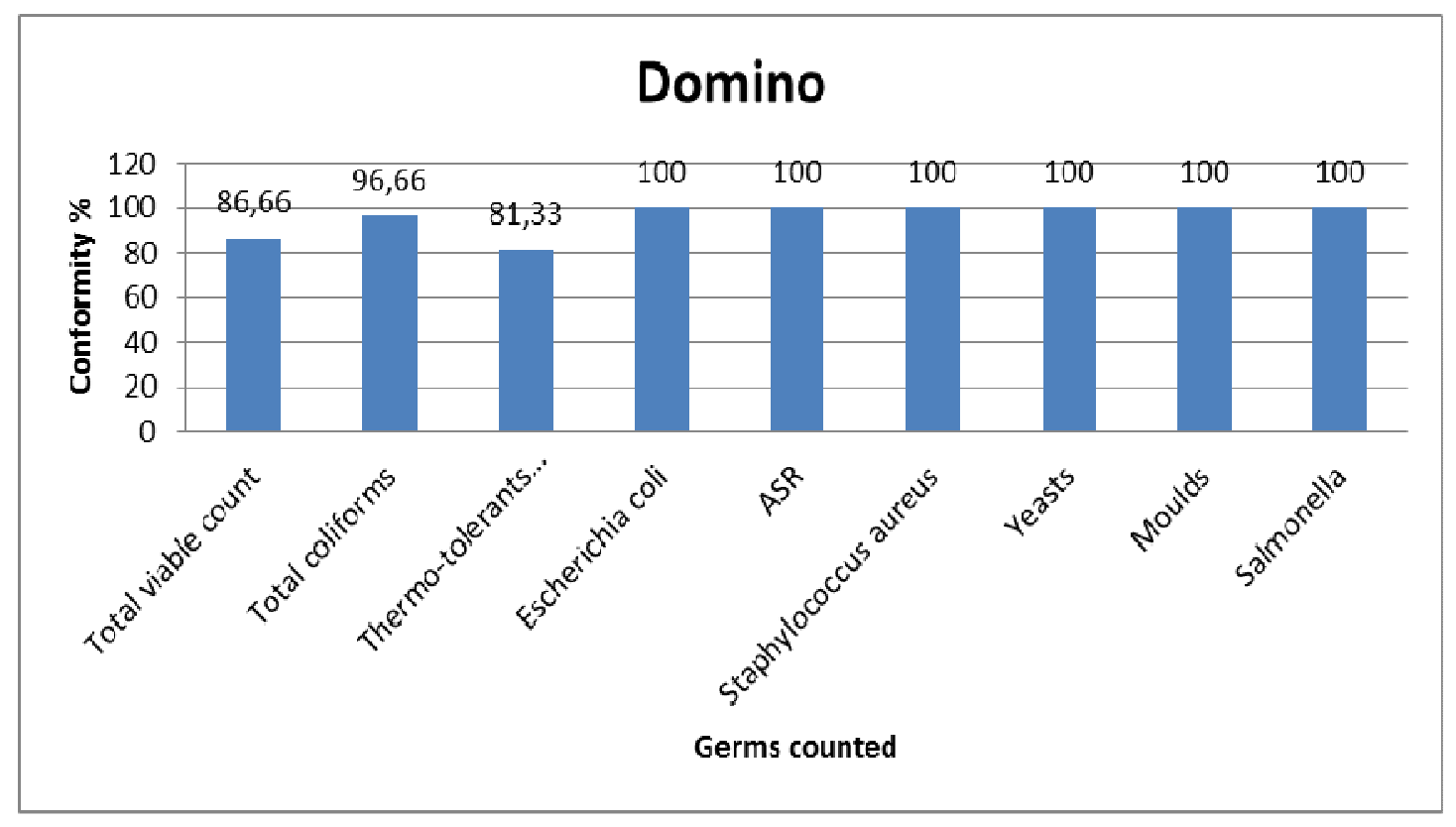

Figure 2: Compliance $(\%)$ level of Domino salad samples compared to the germs. ASR = Anaerobic sulfite-reducing bacteria. 


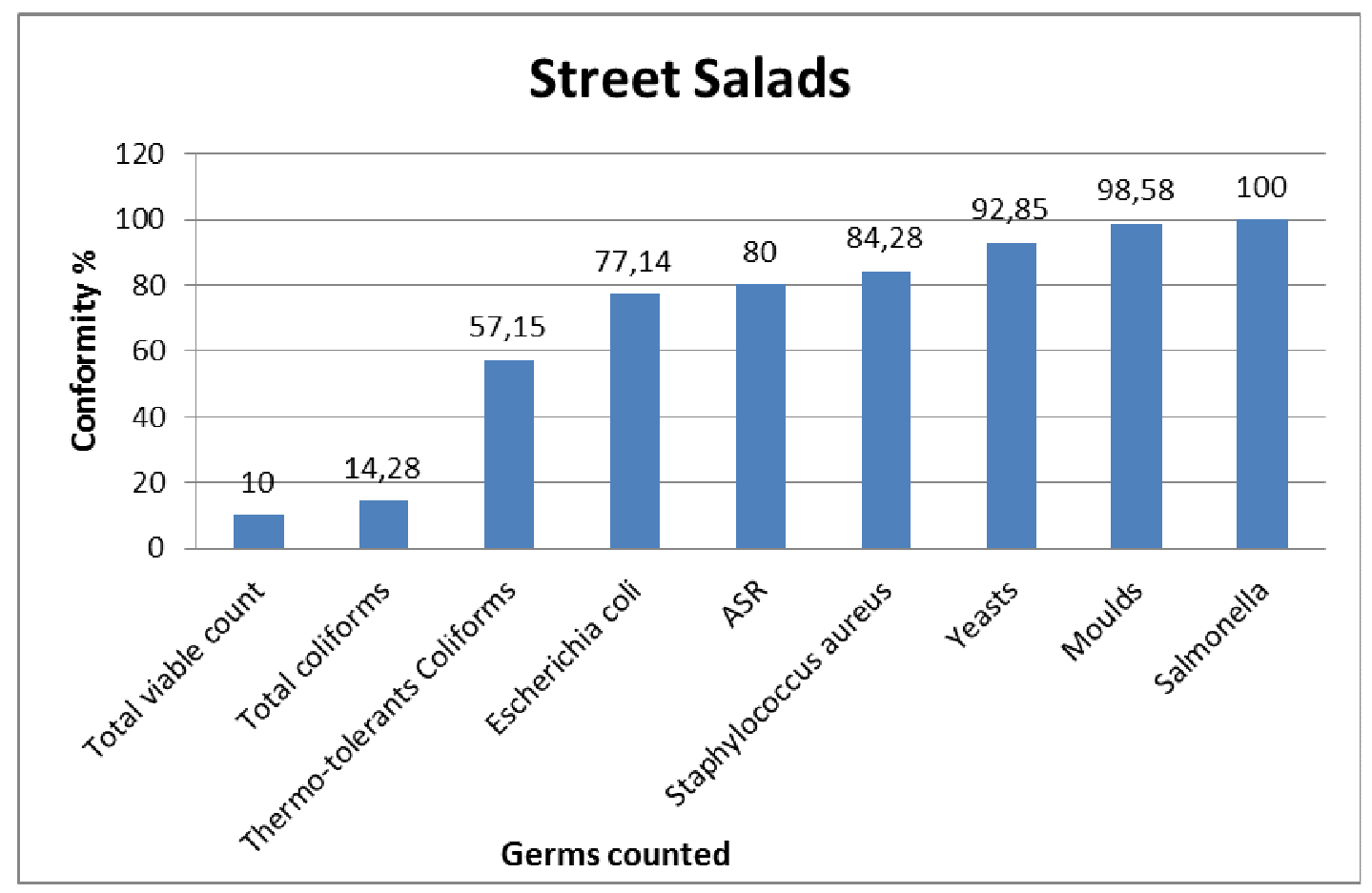

Figure 3: Compliance $(\%)$ level of street salads samples compared to the germs. ASR = Anaerobic sulfite-reducing bacteria.

\section{DISCUSSION}

The results indicated that ready-to-eat salads and fresh ingredients samples from food shops, Domino catering and three markets located in Lomé city were contaminated by most of targeted microorganisms. Thus samples were contaminated by TVC, coliforms, Escherichia coli, S. aureus, Yeasts and Moulds and ASR bacteria. However, the microbial loads of salads samples from street vendors were more contaminated than those of Domino restaurant.

Food safety problems in the developed countries differ from those of developing countries, since in developing countries, traditional methods of processing and packaging, improper holding temperature, poor personal hygiene of food handlers are still observed during food marketing and technology (Collins, 2001; Barro et al., 2002; Mensah et al., 2002). Adjrah et al. (2011) reported that people of Lomé treat their vegetables by various products such as potassium permanganate $(25 \%)$, salt $(22 \%)$, sodium hypochlorite (18\%) and vinegar $(5 \%)$. Odu and Okomuda (2013) thought that since the vegetables are ready-to-eat and will not be subjected to heat treatment, it could be a source of food poisoning to consumers. Watering or washing water can cause microbial contamination of raw vegetables (Tiimub et al., 2012). Some ready-to-eat foods as salads, are regarded as 'potentially hazardous' (Tambekar and Mundhaba, 2006). Ready-to-eat salads that can support the growth of pathogenic bacteria must be kept at low temperatures to minimize the growth of any pathogens that may be present in food or to prevent toxins production in food. Selling activities are done from 9 a. m. to $3 \mathrm{p}$. m. on room temperature $\left(29{ }^{\circ} \mathrm{C}\right.$ to $\left.35{ }^{\circ} \mathrm{C}\right)$. It is a suitable condition for microorganism growth (Mensah et al., 2002).

Preparation and selling activities in developing countries often contribute to the 
cross contamination of food. Cross contamination occurs when one object becomes contaminated by either direct or indirect contact with another object which is already contaminated. According to Williams et al. (2011), improper handling of raw food products during shopping and transport to the home is a route of exposure for the transmission of these pathogens. Street food handlers use the same utensils to collect raw and ready-to-eat food or fresh vegetables already handled. However, sliced fruits and vegetables are widely exposed to microbial contamination (Nwachukwu et al., 2008). The microbial loads of salads samples from the street vendors of salads (Lomé) were higher than that of Domino restaurant.

According to Feglo and Sakyi (2012), food contamination in developing countries is caused by many factors including traditional food processing methods, inappropriate holding temperatures, and poor personal hygiene of food handlers. Among the vendors sampled, $28.53 \%$ carried an apron during the selling activity. Clothes can be one of the main causes of cross contamination. It is essential to use clean apron to help stop dirt and bacteria getting onto work clothes. In Brazzaville, the use of the water of doubtful quality for the cleaning of the utensil, the fact of handling food with naked hands, the absence of washing of hands, the exposure of food to the flies and the wearing of dirty clothes by the producers and salespersons at the time of manufacture or sale was identified like potential factors of food contamination. (Louembe et al., 2008).

According to the Total viable count bacteria $90 \%$ of street salads samples, $13.34 \%$ of Domino samples (13.34\%) and $47.80 \%$ of raw vegetable samples $(47.8 \%)$ were no conforms (Figure 1). These germs induce more non conformity compared to the bacteria sought in the samples of salads and raw vegetables of Lomé. Adjrah et al. (2013) found that $85.51 \%$ of fresh salads samples of Lomé did not fit the standard according to Total viable count bacteria. Soncy et al.
(2014) found that fresh juices samples sold in Lomé schools did not fit the standard according to Total viable count bacteria (100\%), Total coliforms $(66.31 \%)$ and yeast (82.10\%). In Afyonkarahisar (Turkey), 55.1\% and $54 \%$ ready to eat salads samples were found to be contaminated by more of $10^{6} \mathrm{cfu} / \mathrm{g}$ TVC and $10^{4} \mathrm{cfu} / \mathrm{g}$ coliforms (Pamuk et al., 2013).

Saba and Gonzalez (2012) had admitted according to some Food Research publications, that salad is the second most contaminated food samples in Ghana. But they noticed that the most predominant bacteria in Ghanaians foods are coliforms group bacteria which were found in $38 \%$ to $65 \%$ of food samples analyzed. There are no significant differences between samples ( $p>0.05)$. Total viable count bacteria do not seem to be influenced by the washing methods used to clean vegetables in the two systems of restoration. Gram coloring realized on 123 isolated colonies of the total viable count showed that $93 \%$ were Gram positive bacteria and $7 \%$ were Gram negative bacteria. On the other hand, bacteria isolated by Ali et al. (2011) in ready-to-eat street fresh vegetables and fruits in Dhaka City, were all Gram negative. It seemed that Gram positive bacteria are not influenced by the treatments undergone by the raw material or are the principal germs contaminating salads after their preparation. All the bacteria isolated from tap water samples of Lomé are Gram positive bacilli (Kimassoum, 2011).

The significant difference observed in levels of contamination by coliform bacteria of salad from Domino catering compared to the street could be a reflection of the level of exposure and the handling processes in these two vending sites (Oranusi, Olorunfemi. 2011). Escherichia coli were isolated in fresh vegetables and in street salads. It ranged from 0 to $2.5 \times 103 \mathrm{cfu} / \mathrm{g}$ and from 0 to 120 respectively in salad and fresh ingredients samples analyzed. Cleaning activities don't eliminate vegetables contamination by E. coli. Many other factors would have influenced the 
growth of those germs in the street salads. The presence of $E$. coli, frequently associated with poor sanitary practices could be a pointer to danger of possible foodborne infection (Ofor et al., 2009). E. coli are especially of fecal origin. These are known foodborne pathogens and opportunistic pathogens that have been implicated in foodborne disease outbreaks (Oranusi et al., 2006). Bacteria pathogens being a part of the environment can easily contaminate fruits and vegetables when these commodities are not properly handled prior to consumption. Ofor et al. (2009) therefore suggested that to avoid the infiltration of potential foodborne pathogens such as Salmonella and E. coli into natural openings or harvest wounds of fresh-market tomatoes, or other fruits and vegetables, great attention should be paid to the state of the wash water. Moreover, the poor work conditions: the room temperature, the dust and the obvious risks of cross contamination would be the base of high concentration of its germs in salads of streets. E. coli was not found in salads of Domino. Brooks (2014) observed that this difference might be due to disparity in the processing methods and the sanitation of the production area and personal hygiene of the vendors. Like Tambekar et al. (2011), our findings showed the need for more respect of Good Manufacturing Practices (GMP) and Good Hygiene Practices (GHP) to reduce street foods contamination.

\section{Conclusion}

Data obtained from the microbial analysis suggested that, there was more risk consuming salads sold in street than in the modern restaurant. This was illustrated by the high contamination by coliforms, presence of Escherichia coli and Staphylococcus aureus in salads samples from street vendors. The hazards are less within the structures having good hygienic methods of preparation as Domino restaurant. Accordingly, training must be launched to help training restaurant managers and other staff, inspectors of food safety management systems. One of the measures to ensure improvement of the quality of street foods is to train, recycle and make the regular inspection to all members of food safety management systems.

Moreover, an adequate method of treatment and cleaning of the raw materials, environment, utensils and the good hygiene of the manipulator must be taken to assure a good quality for the product and to significantly reduce the contamination of total viable count of salads.

\section{REFERENCES}

Adjrah Y, Karou DS, Djéri B, Anani K, Soncy K, Ameyapoh Y, de Souza C, Gbeassor M. 2011. Hygienic quality of commonly consumed vegetables, and perception about disinfecting agents in Lomé. Int. F. Res. J., I(18): 1499-1503.

Adjrah Y, Soncy K, Anani K, Blewussi K, Karou DS, Ameyapoh Y, de Souza C, Gbeassor M. 2013. Socio-economic profile of street food vendors and microbiological quality of ready-to-eat salads in Lomé. Int. F. Res. J., 20(1): 65-70.

Ali M, Khan MR, Saha ML. 2011. Antibiotic resistant patterns of bacterial isolates from ready-to-eat (RTE) street vended fresh vegetables and fruits in Dhaka city Bangladesh. J. Sci. Res., 24(2): 127134.

Amponsah-AnnorG, Anamoaba-Baiden E. 2011. Evaluation of Food Hygiene Knowledge Attitudes and Practices of Food Handlers in Food Businesses in Accra, Ghana. Food and Nut. Sci., 2: 830-836.

Arvanitoyannis IS, Bouletis AD, Papa EA, Gkagtzis DC, Hadjichristodoulou C, Papaloucas C. 2011. Microbial and sensory quality of "Lolloverde" lettuce and rocket salad stored under active atmosphere packaging. Anaerobe, 17: 307-309.

Barro N, Nikiéma P, Ouattara CAT, Traoré AS. 2002b. Evaluation de l'hygiène et de la qualité microbiologique de 
quelques aliments de rue et les caractéristiques des consommateurs dans la ville de Ouagadougou et de Bobo-Dioulasso (Burkina Faso). Rev. Sci. Tec. Sci. Santé, 25: 7-21.

Brooks AA. 2014. Evaluation of Microbial Contamination of Street-Vended Fruit Salad in Calabar, Nigeria. Int. J. Curr. Microbiol. App. Sci., 3(7): 1040-1046.

Carrasco E, Pérez-Rodriguez F, Valero A, Garcia-Gimeno RM, Zurera G. 2010. Risk Assessment and Management of Listeria monocytogenes in Ready-toEat Lettuce Salads. Compr. Rev. in Food Sci. and Food Saf., 9: 498-512.

Collins JE. 2001. Impact of changing consumer lifestyles on the emergence/re-emergence of foodborne pathogens. Emer. Inf. Dis., 3: 1-13.

David-Benz H, Wade I, Egg J. 2005. Instabilité des prix et information sur les marchés horticoles au Sénégal: repenser les systèmes d'information sur les marchés agricoles. In : IRAD, INRAB, ISRA et CIRAD, Agriculture et Développement Urbain en Afrique de l'Ouest et du Centre - Recueil des résumés, Atelier International du 31 oct au 3 nov 2005, Palais des Congrès, Yaoundé, Cameroun131-142.

Feglo P, Sakyi K. 2012. Bacterial contamination of street vending food in Kumasi, Ghana. J. Med. Biomed. Sci., 1: $1-8$.

Kimassoum D, Tidjani A, Doutoum AA, Ameyapoh Y, Soncy K, Dossou K, Anani K, de Souza C. 2011. Évaluation de la qualité hygiénique de l'eau de robinet produite par la Société Togolaise des Eaux (TdE) : cas de neuf quartiers de la commune de Lomé (Togo). Microbiol. Hyg. Alim., 23(68) : 51-54.

Lambony PG, Nyassogbo GK. 2008. Lomé : Dynamiques d'une ville africaine, Éditions Karthala, coll. « Hommes et sociétés ».
Louembe D, Kobawila SC, Nyanga-Koumou CAG. 2008. Aliments de rue à Brazzaville: Etude sociodémographique et microbiologique. $A n$. l'Univ. Marien Ngouabi ; Sci. Tec., 9(4) : 69-77.

Meng J, Doyle MP. 2002. Introduction. Microbiological food safety. Micro. and Inf., 4: 395-397.

Mensah P, Yeboah-Manu D, Owusu-Darku K, Ablordey A. 2002. Street Food in Accra, Ghana: how safe are they? Bul. of the World Health Org., 80: 546-556.

Noraziah A, Mohd AA. 2012. The food consumption and eating behavior of Malaysian urbanites: Issues and concerns. Malaysia Journal of Society and Space, 8(6): 157 - 165.

Nwachukwu E, Ezeama C, Ezeanya B. 2008b. Microbiology of polyethylene packaged sliced watermelon sold by street vendors in Nigeria. Afr. J. Microbiol. Res., 2: 192-195.

Odu NN, Okomuda MO. 2013. Bacteriological quality of street-vended Ready-to- eat fresh salad vegetables sold in Port Harcourt Metropolis, Nigeria. Academia Arena., 5(3): 1-11.

Ofor MO, Okorie VC, Ibeawuchi II, Ihejirika GO, Obilo OP Dialoke SA. 2009. Microbial Contaminants in Fresh Tomato Wash Water and Food Safety Considerations in South-Eastern Nigeria. Life Science Journal, 1: 80-82.

Oranusi S, Galadima M, Umoh VJ. 2006. Phage typing and toxigenicity test of $S$. aureus strains from food contact surfaces and foods prepared in boarding schools in Zaria, Nigeria. Nig. J. Microbiol., 20(2): 1011-1017.

Oranusi S, Olorunfemi OJ. 2011. Microbiological safety evaluation of street vended ready-to-eat fruits sold in Ota, Ogun state, Nigeria. International Journal of Research in Biological Sciences, 1(3): 27-32.

Pamuk Ş, Gürler Z, Yildirim Y, Ertaşthe N. 2013. Microbiological Quality of 
Ready to Eat Salads Sold in Afyonkarahisar, Turkey. Kafkas Univ Vet FakDerg, 19(6): 1001-1006, DOI: 10.9775/kvfd.2013.9298.

Rajvanshi A. 2010. Bacterial Load on Street Vended Salads in Jaipur City, India. Int. J. Food Saf., 12: 136-139.

Saba Courage KS, Gonzalez-Zorn B. 2012. Analysis of food safety publications from Ghana. J. Infect. Dev. Ctries, 6(12): 828-835.

Seo KH, Frank JF. 1999. Attachment of Escherichia coli $0157: \mathrm{H7}$ to lettuce leaf surface and bacterial viability in response to chlorine treatment as demonstrated by using confocal scanning laser microscopy. J. Food Prot., 62: 3-9.

Soncy K, Anani K, Adjrah Y, Djeri B, Eklu MM, Karou DS, Ameyapoh Y, de Souza C. 2014. Hygienic Quality and nutrient characterization of three fruits juices sold in Lomé Schools. International Journal of Innovations in Biological and Chemical Sciences, 5: 1-6.

Taban BM, Halkman AK. 2011. Do leafy green vegetables and their ready-to-eat [RTE] salads carry a risk of foodborne pathogens? Anaerobe, 17: 286-287.

Tambekar DH, Mundhada RH. 2006. Bacteriological quality of salad vegetables sold in Amravati City (India). J. Bio. Sci., 6(1): 28-30.
Tambekar DH, Kulkarni RV, Shirsat SD Bhadange DG. 2011. Bacteriological quality of street vended food Panipuri: case study of Amravati City (MS). India. Biosci. Disc., 2(3): 350-354.

Temple R, Minkoua R, Nkendah R Marquis S. 2005. Impact de l'urbanisation sur l'intensification des systèmes de production horticoles au Cameroun. Atelier international sur agriculture et développement urbain en Afrique de l'Ouest et Centre, 31 oct au 3 nov 2005, Yaoundé, Cameroun,1-18.

Tiimub BM, Kuffour RA, Kwarteng AS. 2012. Bacterial Contamination Levels of Lettuce Irrigated with Waste Water in the Kumasi Metropolis. Journal of Biology, Agriculture and Healthcare, 2(10): 116-127.

Uzeh RE, Alade FA, Bankole M. 2009. The microbial quality of pre-packed mixed vegetable salad in some retail outlets in Lagos, Nigeria. Afr. J. Food. Sci., 3: 270-272.

Vrchovska V, Sousa C, Valentao P, Ferreres F, Pereira JA, Seabra RM, Andrade PB. 2006. Antioxidative properties of tronchuda cabbage (Brassica oleracea L. var. costata DC) external leaves against DPPH, superoxide radical, hydroxyl radical and hypochlorous acid. Food Chem., 98: 416-425. 